\title{
PERLINDUNGAN HUKUM TERHADAP HAK-HAK PEKERJA DALAM PERUSAHAAN YANG DINYATAKAN PAILIT ${ }^{*}$
}

Oleh:

\author{
Pande Putu Hendra Andika Putra** \\ Marwanto***
}

A.A Gede Agung Dharmakusuma ${ }^{* * * *}$

\begin{abstract}
ABSTRAK
Pekerja memiliki peran yang sangat penting akan majunya suatu perusahaan, pekerja dan pengusaha dalam dunia bisnis saling membutuhkan, hak dari seorang pekerja dalam perusahaan yang dinyatakan pailit dalam permasalahan ini perlu adanya perlindungan hukum terhadap hak pekerja untuk memperoleh hak mereka. Pailitnya suatu perusahaan menyebabkan hak dari seorang pekerja dipertanyakan dan menimbulkan suatu permasalahan. Tujuan dari masalah ini yaitu untuk mengetahui hak dari seorang pekerja dalam perusahaan yang dinyatakan pailit. Metode yang digunakan dalam penelitian ini adalah penelitian hukum normatif dengan pendekatan perundang-undangan (Statue Approach), pendekatan. Pendekatan konseptual (Conceptual approach). Pendekatan Perbandingan (Comparative Approach). Hasil analisis hak dari seorang pekerja dalam perusahaan yang dinyatakan pailit berhak mendapatkan hak mereka baik berupa perlindungan hukum maupun upah.
\end{abstract}

\section{Kata Kunci: Perlindungan Hukum., Pekerja., Pailit}

\begin{abstract}
Workers have a very important role to play in the advancement of a company, workers and entrepreneurs in the business world of mutual need, the rights of a worker in a company declared bankrupt in this matter need legal protection for the right of workers to obtain their rights. The bankruptcy of a company causes the rights of a worker to be questioned and cause a problem. The purpose of this problem is to
\end{abstract}

\footnotetext{
* Jurnal ini merupakan ringkasan skripsi.

** Pande Putu Hendra Andika Putra merupakan penulis pertama.

${ }^{* * *}$ Marwanto merupakan penulis kedua.

${ }^{* * * *}$ A.A Gede Agung Dharmakusuma merupakan penulis ketiga.
} 
find out the rights of a worker in a company declared bankrupt. The method used in this research is normative legal research with a legal approach (Statue Approach), approach. Conceptual approach. Comparative Approach. The results of the analysis of the rights of a worker in a company declared bankrupt have the right to obtain their rights in the form of both legal protection and wages.

\section{Keywords: Legal Protection., Labor., Bankrupt}

\section{PENDAHULUAN}

\subsection{Latar Belakang}

Pekerja dalam tujuannya untuk mendapatkan suatu upah, sebagaimana disebutkan dalam Pasal 28D ayat (2) Undang-Undang Dasar Republik Indonesia 1945 bahwa "Setiap orang berhak untuk bekerja serta mendapatkan imbalan dan perlakuan yang adil dan layak dalam hubungan kerja”. Pekerja merupakan bagian dari tenaga kerja yang telah melakukan pekerjaan dan atas jasanya dalam bekerja yang bersangkutan mendapat upah atau imbalan lain. ${ }^{1}$ Dalam menjalani sebuah perusahaan pengusaha memerlukan tenaga kerja untuk dapat membantu mengoperasionalkan perusahaannya untuk mendapatkan keuntungan. ${ }^{2}$ Perlindungan pekerja dapat dilakukan baik dengan jalan memberikan tuntunan. Pada konsiderans huruf d Undang-Undang Nomor 13 Tahun 2003 Tentang Ketenagakerjaan menyatakan bahwa perlindungan terhadap tenaga kerja dimaksudkan untuk menjamin hak-hak dasar pekerja/buruh

\footnotetext{
${ }^{1}$ Anak Agung Ayu Dian Mentari A, 2016, (Pelaksanaan Perlindungan Bagi Karyawan yang mengalami kecelakaan saat bekerja pada PT.Bayu Putra), Jurnal Ilmiah Vol 4 no 05 oktober 2016, Kertha Semaya, h.2, https://ojs.unud.ac.id, diakses tanggal 12 Maret 2019.

${ }^{2}$ Prabandari, P, R, 2014, "Kedudukan Hukum Perusahaan bentuk Usaha Tetap (Permanent Establishment) Dalam Dimensi Hukum Penanaman Modal Di Indonesia”, Jurnal Magister Hukum (Udayana Magister Law Journal), 2(3), h.440, URL: http://ojs.unud.ac.id/indek.php/jmhu/article/view/10945/7770, diakses tanggal 13 juni 2019, pukul 13.30 .
} 
dan menjamin kesamaan kesempatan serta perlakuan tanpa diskriminasi atas dasar apapun untuk mewujudkan kesejahteraan pekerja/buruh dan keluarganya dengan tetap memperhatikan perkembangan kemajuan dunia usaha. Undang-Undang Republik Indonesia tentang Ketenagakerjaan yang mengatur hak buruh pada saat pailit, disisi lain terdapat Undang-Undang yang mengatur tentang Kepailitan dengan demikian terjadi benturan antara pemenuhan hak karyawan yang didahulukan berdasarkan UndangUndang Ketenagakerjaan atau Undang-Undang Kepailitan.Pailit dalam penjelasan pasal 2 ayat (1) Undang-Undang Nomor 37 Tahun 2004 yakni suatu keadaan dimana debitor tidak membayar lunas satu utang yang telah jatuh waktu yang dapat ditagih dan dinyatakan pailit dengan putusan pengadilan baik atas permohonannya sendiri maupun atas permohonan satu atau lebih kreditornya.

Pailitnya PT. Hardys Retailindo mengakibatkan banyaknya pertanyaan dari para pekerja tentang nasib tujuan mereka bekerja yaitu upah, Bangkrut diidentikan dengan keadaan seseorang yang tidak mampu lagi membayar utang atau mengalami kegagalan dalam usahanya. ${ }^{3}$ Sebelumnya untuk melunasi sebagian utangnya, Hardiawan menyatakan telah menjual 17 outlet Hardys yang tersebar di seluruh Bali, termasuk di Jawa Timur. Adapun yang membeli yaitu pengusaha asal Singaraja, I Gede Sedana. ${ }^{4}$ Dalam masalah ini lah penulis mengangkat judul "PERLINDUNGAN HUKUM TERHADAP HAK-HAK PEKERJA DALAM PERUSAHAAN YANG DINYATAKAN PAILIT".

${ }^{3}$ Jono, 2008, Hukum Kepailitan, Sinar Grafika, Jakarta, h.1.

4"Hardys Pailit, Penglola diambialih", URL : http://www. nusabali.com/2017/19/11, di akses pada tanggal 7 oktober 2018 . 


\subsection{Rumusan Masalah}

Bagaimana pengaturan hak-hak dan kewajiban pekerja terhadap perusahaan yang dinyatakan pailit dan apakah hak-hak pekerja terhadap PT. Hardys Retailindo yang dinyatakan pailit oleh pengadilan niaga?

\subsection{Tujuan Penulisan}

Tujuan penelitian ini adalah untuk mengetahui pengaturan hak-hak dan kewajiban pekerja terhadap perusahaan yang dinyatakan pailit, serta untuk mengetahui hak-hak pekerja PT. Hardys Retailindo yang dinyatakan pailit oleh pengadilan niaga.

\section{ISI MAKALAH}

\subsection{Metode}

Jenis metode yang digunakan dalam jurnal ini yaitu menggunakan metode penelitian hukum normatif. Penelitian hukum normatif adalah penelitian hukum yang melekatkan hukum sebagai sebuah bangunan sistem norma. Sistem norma yang dimaksud yaitu asas-asas, norma, kaidah dari peraturan perundang-undangan, putusan pengadilan, perjanjian serta doktrin (ajaran). ${ }^{5}$ Adapun ciriciri dari penelitian normatif adalah penelitian beranjak dari adanya kesenjangan dalam norma hukum/asas hukum, tidak menggunakan hipotesa, menggunakan landasan teori, menggunakan bahan hukum primer, bahan hukum sekunder, dan bahan hukum tersier. ${ }^{6}$

Pendekatan yang digunakan dalam penelitian ini adalah pendekatan perundang-undangan (the statutory approach) digunakan

\footnotetext{
${ }^{5}$ Mukti Fajar BD Yulianto Ahmad, 2010, Dualisme Penelitian Hukum Normatif\&Empiris, Pustaka Pelajar, Yogyakarta, h. 34.

${ }^{6}$ Amiruddin, Zainal azikin, 2004, Pengantar Metode Penelitian Hukum, RajaGrafindo Prasada, Jakarta, h.166.
} 
untuk menelaah aturan hukum terkait pengaturan hak-hak pekerja terhadap perusahaan yang dinyatakan pailit. Pendekatan konseptual (conceptual approach) digunakan untuk memahami konsep-konsep yang terkandung dalam Undang-Undang Ketenagakerjaan dan Undang-Undang Kepailitan dan Penundaan Kewajiban Pembayaran Utang. Pendekatan Perbandingan dimana dalam kasus ini pendekatan perbandingan ini digunakan untuk membandingkan antara Undang-Undang Ketenagakerjaan dengan Undang-Undang Kepailitan dan Penundaan Kewajiban Pembayaran Utang.

Sumber bahan hukum dalam suatu penelitian yang bersifat normatif, data yang diteliti terdapat dua jenis yaitu primer dan sekunder. Data sekunder adalah data yang bersumber dari penelitian kepustakaan. ${ }^{7}$ Data sekunder adalah data yang diperoleh dari bukubuku hukum termasuk skripsi, tesis, dan disertai hukum dan jurnaljurnal hukum. Di samping itu juga, kamus-kamus hukum dan komentar-komentar atas putusan pengadilan. ${ }^{8}$ Dalam hal ini data primer yang diperoleh dalam kasus tersebut yaitu dari UndangUndang Dasar Negara Republik Indonesia Tahun 1945, Kitab Undang-Undang Hukum Perdata Terjemah oleh Soedharyo Soimin, Undang-Undang Nomor 13 Tahun 2003 Tentang Ketenagakerjaan Dan Undang-Undang Nomor 34 Tahun 2004 Tentang Penundaan Kewajiban Pembayaran Utang, Peraturan Pemerintah Republik Indonesia Nomor 78 Tahun 2015 Tentang Pengupahan, dan Putusan Pengadilan Surabaya SURABAYA Nomor 29/Pdt.Sus-PKPU/2017/PN NIAGA Sby Tahun 2017.

7Fakultas Hukum Universitas Udayana, 2013, Pedoman Pendidikan Fakultas Hukum Universitas Udayana, Bali, h, 81.

${ }^{8}$ Peter Mahmud Marzuki, 2010, Penelitian Hukum, Cer. VIII, Kencana Predana Media Group, Jakarta, h. 195. 


\subsection{Hasil dan Analisis}

\subsubsection{Pengaturan hak-hak dan kewajiban pekerja terhadap perusahaan yang dinyatakan pailit}

Suatu hubungan hukum yang selalu lahir baik dari perikatan maupun peraturan perundang-undangan selalu menyertakan dua aspek yaitu hak dan kewajiban. Menurut Subekti, perjanjian (overeenkomst) adalah suatu persitiwa dimana seorang berjanji kepada seorang lain atau di mana dua orang itu saling berjanji untuk melaksanakan suatu hal. ${ }^{9}$ Sebagai pekerja/buruh maka hak atas upah yang adil merupakan hak legal yang diterima dan dituntut seseorang sejak para pekerja/buruh mengikatkan diri untuk bekerja pada suatu perusahaan baik pada perusahaan swasta maupun instansi pemerintah. ${ }^{10}$ Hak dasar tenaga kerja yaitu :

1. Hak memperoleh perlakuan yang sama tanpa diskriminasi

2. Hak memperoleh pelatihan kerja

3. Hak Pengakuan Kompetensi dan Kualifikasi Kerja

4. Hak Memilih Penempatan Kerja

5. Hak-Hak Pekerja Perempuan

6. Hak Lamanya Waktu Bekerja

7. Hak Bekerja Lembur

8. Hak Istirahat dan Cuti Bekerja

9Simanjutak, 2015, "Hukum Perdata Indonesia", Prenadamedia Group, Jakarta , h.285.

10I Gusti Agung Yoga Bhaskara Susila, 2018, "Perlindungan Hukum Terhadap Hak-Hak security Outsourcing Menurut Putusan MK.No27/PUUXI/2011(Studi Kasus di:PT Mandala Security", Jurnal Ilmiah Vol 06 no 05 November 2018, Kertha Semaya, h.2, https://ojs.unud.ac.id, diakses tanggal 12 Juni 2019. 
9. Hak Beribadah

10. Hak Perlindungan Kerja

11. Hak Mendapatkan Upah

12. Hak Kesejahteraan

13. Hak bergabung dengan serikat pekerja

14. Hak Mogok Kerja

15. Hak Uang Pesangon

Pada asasnya, upah tidak dibayar apabila pekerja tidak melaksanakan pekerjaan. ${ }^{11}$ Upah yang diterima oleh Pekerja/buruh merupakan bentuk prestasi dari suatu pengusaha ketika dari buruh itu sendiri telah memberikan suatu prestasi kepada pengusaha yang dalam hal ini suatu pekerjaan dan jasa yang telah dilakukan oleh pekerja/buruh tersebut. karena menjadi suatu hak normatif, maka Peraturan Perundang-undangan yang mengatur tentang pengupahan memuat suatu sanksi bagi pengusaha yang dalam hal ini mengabaikan peraturan perundang-undangan terkait masalah pengupahan dan perlindungan upah. Jika pengusaha melanggar peraturan tersebut, maka pengusaha tersebut termasuk dalam tindak pidana kejahatan. Dalam Undang-undang Dasar 1945 pasal 27 ayat (2) menjelaskan :

${ }^{11} \mathrm{Ni}$ Luh Kurnia Dharma Pertiwi, 2016, "Akibat Hukum Terhadap Pengusaha Yang Melakukan Penahanan Upah Kepada Pekerja Yang Tidak Disiplin", Jurnal Ilmiah Vol 04 no 02 februari 2016, Kertha Semaya, h.2, https://ojs.unud.ac.id, diakses tanggal 12 juni 2019. 
"Tiap-tiap warga Negara berhak atas pekerjaan dan penghidupan yang layak bagi kemanusiaan"

Berdasarkan Peraturan Pemerintah Nomor 78 Tahun 2015 tentang pengupahan, diatur juga Pembayaran Upah dalam Keadaan Kepailitan :

1. Pasal 37

(1) Pengusaha yang dinyatakan pailit berdasarkan putusan pernyataan pailit oleh pengadilan maka Upah dan hakhak lainnya dari Pekerja/Buruh merupakan hutang yang didahulukan pembayarannya.

(2) Upah Pekerja/Buruh sebagaimana dimaksud pada ayat (1) didahulukan pembayarannya sesuai dengan ketentuan peraturan perundang-undangan.

(3) Hak-hak lainnya dari Pekerja/Buruh sebagaimana dimaksud pada ayat (1) didahulukan pembayarannya setelah pembayaran para kreditur pemegang hak jaminan kebendaan.

Salah satu yang menjadi kewajiban seorang majikan, pengusaha, atau pemberi kerja yaitu memberikan upah kepada pekerja tepat pada waktunya. ${ }^{12}$ Adapun di dalam KUH Perdata ketentuan mengenai kewajiban buruh/pekerja diatur dalam pasal sebagai berikut :

a. Pasal 1603

${ }^{12}$ Griselda Nadya billy, 2019, "Kewajiban Pengusaha Dalam Pemberian Upah Minimum Pekerja Pasca Putusan Mahkamah Konstitusi Nomor:72/PUU-XIII/2015", Jurnal Ilmiah Vol 07 no 04 maret 2019, Kertha Semaya, h.2, https://ojs.unud.ac.id, diakses tanggal 12 juni 2019. 
Buruh wajib melakukan pekerjaan yang diperjanjikan menurut kemampuannya dengan sebaik-baiknya. Jika sifat dan luasnya pekerjaan yang harus dilakukan tidak dirumuskan dalam perjanjian atau reglemen, maka hal itu ditentukan oleh kebiasaan.

b. Pasal 1603 a

Buruh wajib melakukan sendiri pekerjaannya, hanya dengan ijin majikan ia dapat menyuruh orang lain menggantikannya.

c. Pasal 1603 b

Buruh wajib menaati aturan-aturan pelaksana pekerjaan dan aturan-aturan yang dimaksudkan untuk perbaikan tata tertib perusahaan majikan yang diberikan oleh atau atas nama majikan yang diberikan oleh atau atas nama majikan dalam batas-batas aturan perundang-undangan, perjanjian atau reglemen, atau jika ini tidak ada, dalam batas-batas kebiasaan.

d. Pasal 1603 c

Buruh yang tinggal menumpang dirumah majikan wajib berkelakuan menurut tata tertib rumah tangga majikan.

e. Pasal $1603 \mathrm{~d}$

Pada umumnya buruh wajib melakukan atau tidak melakukan segala sesuatu yang dalam keadaan yang sama seharusnya dilakukan atau tidak dilakukan oleh seorang buruh yang baik. 


\subsubsection{Hak Pekerja Terhadap PT. Hardys Retailindo Yang Dinyatakan Pailit Pasca Putusan Pengadilan Niaga}

Perlindungan hukum terhadap pekerja pada dasarnya bertujuan untuk menghapus sistem perbudakan dan menjaga agar para tenaga kerja lebih dimanusiakan dengan hal itu sehingga dapat meningkatkan suatu kesejahteraan hidup tenaga kerja dan hidup layak sebagai manusia. Perlindungan pekerja yang dimaksud yaitu seperti menjamin hak-hak normatif pekerja. ${ }^{13}$ Berkaitan dengan masalah pengupahan, sudah jelas bahwa pekerja berhak atas pendapat sebagai salah satu bentuk hak yang mereka terima atas kewajiban yang telah mereka laksanakan. ${ }^{14}$

Jika terjadi Pindah-tangan perusahaan, yang dalam hal ini bisa diartikan dengan jual beli perusahaan. Masa kerja Pekerja/Buruh dan peraturan pensiun perusahaan yang di ambil alih tetap berlaku, dalam artian hak untuk mendapatkan pekerjaan yang dimiliki oleh Pekerja/buruh ditanggung oleh pengusaha baru. Perpindahan perusahaan tersebut tidak berpengaruh atau tidak memutuskan hubungan-hubungan kerja, sehingga buruh tidak berhak atas uang jasa dari majikan lama, hal tersebut dapat diartikan bahwa dalam menuntut suatu hak dari Pekerja/Buruh yang dalam hal ini berupa Upah tidak lagi diberikan oleh pengusaha

${ }^{13}$ Putu Gede Aditya Wangsa, 2019, "Keterlambatan Pembayaran Upah Pekerja Oleh PT.Boma Bisma Indra (Persero) Surabaya Menurut Undang-Undang Nomor 13 Tahun 2003 Tentang Ketenagakerjaan”, Jurnal Ilmiah, Vol. 07 nomor 01, Maret 2019, Kertha Semaya, h. 3, https://ojs.unud.ac.id, diakses tanggal 12 Maret 2019.

${ }^{14}$ I Wayan Maydy Pradana Putra, 2018, "Perlindungan Hukum Terhadap Upah Pekerja Di Bawah Umur Pada Wangsuh Loundry Denpasar Timur", Jurnal Ilmiah Vol 06 no 02 oktober 2018, Kertha Semaya, h.4, https://ojs.unud.ac.id, diakses tanggal 12 Juni 2019. 
lama melainkan kewajiban dari pengusaha baru yang memberikan suatu upah untuk para pekerja/Buruh.

Selain bertujuan untuk menghapus sistem perbudakan, perlindungan hukum terhadap tenaga kerja ini dimaksudkan untuk menjamin hak-hak dasar tenaga kerja, dan juga untuk menjamin kesamaan kesempatan dan perlakuan tanpa diskriminasi atas apapun. Lingkup perlindungan terhadap tenaga kerja atau buruh menurut Undang-Undang Nomor 13 Tahun 2003, yaitu :

1. Perlindungan atas hak-hak dasar pekerja atau buruh untuk berunding dengan pengusaha

2. Perlindungan keselamatan dan kesejahteraan kerja

3. Perlindungan khusus bagi para pekerja atau buruh perempuan, anak, dan penyandang cacat

4. Perlindungan tentang upah, kesejahteraan dan jaminan sosial tenaga kerja

Setelah orang yang demikian atas permintaan para kreditornya atau asas atas permintaan sendiri oleh pengadilan dinyatakan pailit, maka harta kekayaan dikuasai oleh balai Harta Peninggalan selaku pengampu dalam urusan kepailitan tersebut untuk dimanfaatkan bagi semua kurator. Menurut R. Subekti dan R. Tjitrosudibio, pailit yaitu keadaan seorang debitor apalagi ia telah menghentikan pembayaran utang-utangnya. Suatu keadaan yang menghendaki campur tangan majelis hakim guna menjamin kepentingan bersama para pihak. ${ }^{15}$ Berdasarkan putusan PN SURABAYA Nomor 29/Pdt.Sus-PKPU/2017/PN Niaga Sby Tahun 2017 tentang perkara pailitnya PT. Hardys Retailindo, analisis tentang perlindungan hukum terhadap hak dari seorang pekerja untuk mendapatkan upah belum

15Viktor Situmorang \& Soekarso, op. cit., h. 18. 
diterima oleh para pekerja dari PT. Hardys Retailindo. Dengan adanya Pemutusan Hubungan Kerja (PHK) putaran pertama pada 9 Januari 2018 hingga putaran kedua pada tanggal 25 Februari 2018 pihak perusahaan telah menjanjikan seluruh pekerja akan mendapatkan hak-haknya. Namun hingga saat ini hak-hak dari pekerja belum diberikan. Berdasarkan Pasal 150 Undang-Undang Nomor 13 Tahun 2003 mengatur tentang:

"Ketentuan mengenai pemutusan hubungan kerja dalam undang-undang ini meliputi pemutusan hubungan kerja yang terjadi di badan usaha yang berbadan hukum atau tidak, milik orang perseorangan, nilik persekutuan atau negara, maupun usaha-usaha sosial dan usaha-usaha lain yang mempunyai pengurus dan mempekerjakan orang lain dengan membayar upah atau imbalan dalam bentuk lain."

Mengacu pada pasal tersebut dalam hal ini hak dari seorang pekerja yaitu untuk mendapatkan upahnya, haruslah diberikan oleh pihak debitor kepada kreditor. Pembayaran upah atau pesangon kepada pekerja PT. Hardys Retailindo yang dalam hal ini telah menuntut hak-hak mereka berupa uang pengganti sisa cuti tersebut bekerja selama satu sampai 17 tahun lamanya. PT Artha Sedana Retailindo yang dalam hal ini sebagai pengganti dari PT Hardys Retailindo tidak sanggup membayar pesangon pekerja sejak manajemen masih dibawah naungan PT Hardys Retailindo, pesangon atau hak lainnya yang mampu dibayarkan hanya sejak perusahaan tersebut diambil alih oleh PT. Artha Sedana Retailindo. Hingga saat ini hak untuk mendapatkan pesangon atau upah pasca PT Hardys dinyatakan pailit untuk pekerja belum dibayarkan oleh pihak PT. Hardys Retailindo. 


\section{PENUTUP}

\subsection{Kesimpulan}

Hak-hak dan kewajiban pekerja terhadap perusahaan yang dinyatakan pailit, berhak untuk mendapatkan hak mereka dan wajib melakukan pekerjaan mereka.Hak dari seorang pekerja PT. hardys Retailindo pasca dinyatakan pailit yaitu dengan hal ini pekerja berhak mendapatkan perlindungan hukum guna mendapatkan hak pesangon atau pengganti sisa cuti. Dalam perkara PT. Hardys Retailindo yang dinyatakan pailit hak hak dari seorang pekerja belum diberikan setelah PT. Hardys Retailindo dinyatakan pailit.

\subsection{Saran}

Pemerintah dalam hal ini berperan penting dalam memperkuat atau menegaskan kembali Undang-Undang Ketenagakerjaan, agar dalam pengaturannya hak dari pekerja lebih diutamakan atau tidak dikesampingkan dan kewajiban dari pekerja lebih ditegaskan kembali. Berdasarkan hak-hak pekerja PT. hardys Retailindo yang dinyatakan pailit oleh pengadilan niaga, berdasarkan pasal 150 Undang-Undang Ketenagakerjaan, dengan maksud pekerja dalam hal ini berhak mendapatkan upah.

\section{DAFTAR PUSTAKA}

\section{Buku}

Amiruddin, Zainal azikin, 2004, Pengantar Metode Penelitian Hukum, RajaGrafindo Prasada, Jakarta.

Bambang Sunggono, 2007, Metode Penelitian Hukum, Rajawali Pers, Jakarta

Jono, 2008, Hukum Kepailitan, Sinar Grafika, Jakarta. 
Peter Mahmud Marzuki, 2010, Penelitian Hukum, Cer. VIII, Kencana Predana Media Group, Jakarta.

Simanjutak, 2015, Hukum Perdata Indonesia, Prenadamedia Group, Jakarta.

Syamsudin M. Sinaga, 2012, Hukum Kepailitan Indonesia, Tatanusa, Jakarta.

\section{Jurnal}

Aditya Wangsa, Putu Gede, 2019, "Keterlambatan Pembayaran Upah Pekerja Oleh PT.Boma Bisma Indra (Persero) Surabaya Menurut Undang-Undang Nomor 13 Tahun 2003 Tentang Ketenagakerjaan", Jurnal Ilmiah, Vol. 07 nomor 01, Maret 2019, Kertha Semaya h.3, https://ojs.unud.ac.id, diakses tanggal 12 Maret 2019.

Ayu Dian Mentari A, Anak Agung , 2016,"Pelaksanaan Perlindungan Bagi Karyawan yang mengalami kecelakaan saat bekerja pada PT.Bayu Putra", Jurnal Ilmiah Vol 04 no 05 oktober 2016, Kertha Semaya, h.2, https://ojs.unud.ac.id, diakses tanggal 12 Maret 2019.

Griselda Nadya billy,2019,"Kewajiban Pengusaha Dalam Pemberian Upah Minimum Pekerja Pasca Putusan Mahkamah Konstitusi Nomor:72/PUU-XIII/2015", Jurnal Ilmiah Vol 07 no 04 maret 2019, Kertha Semaya, h.2, https://ojs.unud.ac.id, diakses tanggal 12 juni 2019.

Kurnia Dharma Pertiwi, Ni Luh, 2016, "Akibat Hukum Terhadap Pengusaha Yang Melakukan Penahanan Upah Kepada Pekerja Yang Tidak Disiplin", Jurnal Ilmiah Vol 04 no 02 februari 2016, Kertha Semaya, h.2, https://ojs.unud.ac.id, diakses tanggal 12 juni 2019.

Maydy Pradana Putra, I Wayan, 2018, "Perlindungan Hukum Terhadap Upah Pekerja Di Bawah Umur Pada Wangsuh Loundry Denpasar Timur", Jurnal Ilmiah Vol 06 no 02 oktober 2018, Kertha Semaya, h.4, https://ojs.unud.ac.id, diakses tanggal 12 Juni 2019. 
Prabandari, P, R, 2014, "Kedudukan Hukum Perusahaan bentuk Usaha Tetap (Permanent Establishment) Dalam Dimensi Hukum Penanaman Modal Di Indonesia", Jurnal Magister Hukum (Udayana Magister Law Journal), 2(3), h.440, URL: http://ojs.unud.ac.id/indek.php/jmhu/article/view/10945/77 70, diakses tanggal 13 juni 2019, pukul 13.30.

Yoga Bhaskara Susila, I Gusti Agung, 2018, "Perlindungan Hukum Terhadap Hak-Hak security Outsourcing Menurut Putusan MK.No27/PUU-XI/2011 (Studi Kasus di:PT Mandala Security", Jurnal Ilmiah Vol 06 no 05 November 2018, Kertha Semaya, h.2, https://ojs.unud.ac.id, diakses tanggal 12 Juni 2019.

\section{Internet}

"Hardys Pailit, Penglola diambialih", URL : http://www. nusabali.com/2017/19/11, di akses pada tanggal 7 oktober 2018.

\section{Peraturan Perundang-Undangan}

Kitab Undang-Undang Hukum Perdata, (Burgerlijck wetbook di Terjemahkan oleh Soedharyo Soimin), Sinar Grafika.

Indonesia, Undang-Undang Dasar Negara Republik Indonisa Tahun 1945

Indonesia, Undang-Undang Ketenagakerjaan Dan Peraturan Pemerintah Nomor 78 Tahun 2015 Tentang Pengupahan

Indonesia, Undang-Undang Nomor 37 Tahun 2004 Tentang Kepailitan dan Penundaan Kewajiban Pembayaran Utang 